\title{
Ultra-large Specific Surface Area Activated Carbon Synthesized from Rice Husk with High Adsorption Capacity for Methylene Blue
}

\author{
ZHOU Fan ${ }^{1,2}$, BI Hui ${ }^{1}$, HUANG Fuqiang ${ }^{1,2,3}$ \\ (1. State Key Laboratory of High Performance Ceramics and Superfine Microstructure, Shanghai Institute of Ceramics, Chinese \\ Academy of Sciences, Shanghai 200050, China; 2. School of Physical Science and Technology, ShanghaiTech University, \\ Shanghai 200031, China; 3. State Key Laboratory of Rare Earth Materials Chemistry and Applications, College of Chemistry \\ and Molecular Engineering, Peking University, Beijing 100871, China)
}

\begin{abstract}
Activated carbon with high surface area and abundant pore structure is widely used for contaminant adsorption in wastewater treatment. Rice husks (RHs) with unique composition and microstructure are often used as carbon source to prepare activated carbon. Herein, ultra-large specific surface area activated carbon was synthesized from rice husks with pre-activation and activation by supersaturated $\mathrm{KOH}$ solution at different temperatures. With the increase of activation temperature, the specific surface area and total pore volume of activated carbon gradually increase. The activated carbon obtained at $900{ }^{\circ} \mathrm{C}$ shows the largest specific surface area of $3600 \mathrm{~m}^{2} / \mathrm{g}$ and the maximal total pore volume of $3.164 \mathrm{~cm}^{3} / \mathrm{g}$, which are significantly superior to those of the commercial activated carbon (YP-80, the specific surface area of $1310 \mathrm{~m}^{2} / \mathrm{g}$ and the total pore volume of $0.816 \mathrm{~cm}^{3} / \mathrm{g}$, respectively). The highest maximum adsorption capacity for methylene blue was found for the activated carbon with the largest specific surface area, namely, $983 \mathrm{mg} / \mathrm{g}$, which is almost twice as high as that of YP-80 (525 mg/g). By adsorption kinetics fitting, the results are consistent with pseudo-second-order model which indicates that the process of adsorbing methylene blue is chemical adsorption.
\end{abstract}

Key words: rice husk; ultra-large specific surface area; activated carbon; adsorption; methylene blue

Activated carbon (AC) has been always appealing to researchers' attention due to its excellent properties and versatility. Relying on their low-cost stocks, large specific surface area $\left(\mathrm{SSA}_{\mathrm{BET}}\right)$, abundant pore structure, high chemical stability and non-toxicity, AC has been widely applied to treat waste water containing methylene blue (MB) ${ }^{[1]}$. The MB is commonly utilized for hair colorant, textile dyeing, coloring paper and so on $^{[2]}$. Because of carcinogenesis effect, the amount of MB in the body is large enough to cause cancer, mutation and dermatological diseases ${ }^{[3]}$. Therefore, removing MB from waste water is significantly important.

The synthesis methods of $\mathrm{AC}$ include physical and chemical activation with microwave heating assisting occasionally. Various agricultural wastes are used as raw materials, such as peanut hull ${ }^{[4]}$, tea-leaves ${ }^{[5]}, \operatorname{cotton}^{[6]}$, coconut husks ${ }^{[7]} \cdot \mathrm{CO}_{2}$ and water vapor are applied as activating agents in physical activation ${ }^{[8-9]} \cdot \mathrm{ZnCl}_{2}, \mathrm{KOH}$ and $\mathrm{H}_{3} \mathrm{PO}_{4}$ are usually utilized as activator in chemical activation ${ }^{[10-12]}$. Bellington, et al. ${ }^{[13]}$ utilized $\mathrm{ZnCl}_{2}$ to activate tobacco stems with microwave heating, and the product got the $\mathrm{SSA}_{\mathrm{BET}}$ of $684.68 \mathrm{~m}^{2} / \mathrm{g}$ and the maximum adsorption capacity of $123.45 \mathrm{mg} / \mathrm{g}$ for adsorbing MB. Viscose-based AC fibers were prepared by steam with different flows at $900{ }^{\circ} \mathrm{C}$ for the adsorption of $\mathrm{MB}$, and they performed the $\mathrm{SSA}_{\mathrm{BET}}$ of $1614 \mathrm{~m}^{2} / \mathrm{g}$ and the adsorption capacity of $325.8 \mathrm{mg} / \mathrm{g}^{[9]}$. Bamboo shoots were activated by $\mathrm{KHCO}_{3}$ to prepare $\mathrm{AC}$ for removing MB from waste water, which exhibited the $\mathrm{SSA}_{\mathrm{BET}}$ of $2271 \mathrm{~m}^{2} / \mathrm{g}$ and the maximum adsorption capacities of $458 \mathrm{mg} / \mathrm{g}^{[14]}$. Obviously, the $\mathrm{SSA}_{\mathrm{BET}}$ of AC has an essential impact on the adsorption capacity for MB. Therefore,

\footnotetext{
Received date: 2020-11-05; Revised date: 2020-12-08; Published online: 2020-12-10

Foundation item: National Key Research and Development Program of China (2016YFB0901600); National Natural Science Foundation of China (51972326, 51672295, 21871008, 51672301); Science and Technology Commission of Shanghai (18YF1427200); The Key Research Program of Chinese Academy of Sciences (QYZDJ-SSW-JSC013)

Biography: ZHOU Fan (1994-), male, Master candidate. E-mail: 1175106021@qq.com

周 帆(1994-), 男, 硕士研究生. E-mail: 1175106021@qq.com

Corresponding author: HUANG Fuqiang, professor. E-mail: huangfq@mail.sic.ac.cn 黄富强, 研究员. E-mail: huangfq@mail.sic.ac.cn
} 
there exists a great challenge to find a certain kind raw material or method for the preparation of $\mathrm{AC}$ with larger SSA BET.

As an abundant agricultural bio-waste, RHs which hollow fibers are assembled by cellulose, hemicellulose, lignin and significant amounts of $\mathrm{SiO}_{2}$ of about 20wt $\%$ have great potential to prepare AC with ultra-high $\mathrm{SSA}_{\mathrm{BET}}$ owning to their natural structure and component ${ }^{[15]}$. Most of $\mathrm{SiO}_{2}$ and spacious carbon skeleton exist in the outer glume of RHs. The inner glume of RHs is composed of a large number of bundles of vascular tubes to transport nutrients ${ }^{[16]} \cdot \mathrm{SiO}_{2}$ as a hard template can react with molten alkali in the activation process to provide some pore structure. In the subsequent activation, pores formed are further broadened in the original $\mathrm{SiO}_{2}$ sites. It has also been reported that $\mathrm{NaOH}$ can be used as activator to prepare AC showing relatively large $\mathrm{SSA}_{\mathrm{BET}}$ of $1873 \mathrm{~m}^{2} / \mathrm{g}$ based on $\mathrm{RHs}^{[17]}$.

In this study, supersaturated $\mathrm{KOH}$ solution was adopted to prepare $\mathrm{AC}$ with ultra-large $\mathrm{SSA}_{\mathrm{BET}}$ based on the unique advantages of RHs. MB adsorption experiment on the RHAC was conducted to explore the influence of temperature on the $\mathrm{SSA}_{\mathrm{BET}}$ and the adsorption capacity. The $\mathrm{SSA}_{\mathrm{BET}}$, pore structure, and adsorption capacity of RHACs were compared with other AC materials made from other agricultural bio-waste such as tobacco stalk, viscose fibers and sawdust.

\section{Experimental}

\subsection{Materials and synthesis}

The raw RHs were bought from the Taobao network. The received RHs were washed with the deionized water to eliminate the impurities. Then, they were put into drying oven at $60{ }^{\circ} \mathrm{C}$ for $24 \mathrm{~h}$. Potassium hydroxide (AR, 90\%) was purchased from the Aladdin. Methylene Blue trihydrate (biotechnology grade) was bought from the Shanghai Macklin Biochemical Co., Ltd. Hydrochloric acid (AR) and hydrofluoric acid (AR) were purchased from the Shanghai Hushi Laboratorial Equipment Co., Ltd.

The raw RHs were pyrolyzed at $400{ }^{\circ} \mathrm{C}$ in the argon atmosphere for $1 \mathrm{~h}$ in the horizontal tubular furnace to obtain RH biochar (RHBC). RHBC (4 g) and $\mathrm{KOH}$ solution $(2 \mathrm{~mol} / \mathrm{L}, 107 \mathrm{~mL})$ were mixed and stirred for $30 \mathrm{~min}$. The mixture was put into a drying oven at $100{ }^{\circ} \mathrm{C}$ for $48 \mathrm{~h}$ to remove water. The dry mixture was heat-treated in the horizontal tubular furnace in the argon atmosphere for $2 \mathrm{~h}$ at $700{ }^{\circ} \mathrm{C}$ to produce RHAC1. RHBC $(4 \mathrm{~g}), \mathrm{KOH}(12 \mathrm{~g})$ and $25 \mathrm{~mL}$ deionized water are used to produce RHAC2 and the preparation method is the same as that of RHAC1.
RHBC (8 g), KOH (32 g) and $50 \mathrm{~mL}$ deionized water were mixed and stirred for $30 \mathrm{~min}$. The mixture was put into a drying oven at $100{ }^{\circ} \mathrm{C}$ for $48 \mathrm{~h}$ to remove water. The dry mixture was heat-treated in the horizontal tubular furnace in the argon atmosphere for $2 \mathrm{~h}$ under $600,700,800$ and $900{ }^{\circ} \mathrm{C}$ at heating rate of $13{ }^{\circ} \mathrm{C} / \mathrm{min}$ to produce RHAC600, RHAC700, RHAC800 and RHAC900, respectively. The impurities including alkalis, alkali oxides and silica in products were removed by $\mathrm{HCl}$ and HF mixture solutions for $48 \mathrm{~h}$. Finally, all of RHAC were washed with the deionized water and dried in an oven at $120{ }^{\circ} \mathrm{C}$ for $12 \mathrm{~h}$.

\subsection{Characterizations}

Surface morphology was investigated by scanning electron microscope (SEM-JMS-6510). Highly resolution transmission electron microscope (HRTEM) images were conducted on JEOL 2100F. The crystalline structure was carried on Bruker D8 X-ray diffractometer with the source of $\mathrm{Cu} \mathrm{K} \alpha$ radiation at $40 \mathrm{kV}$ and $40 \mathrm{~mA}$. Raman spectra was measured on a thermal dispersive spectrometer using a $10 \mathrm{~mW}$ laser (532 nm). Nitrogen adsorptiondesorption isotherm was measured on a Micromeritics Tristar 3000 system at $77 \mathrm{~K}$. The $\mathrm{SSA}_{\mathrm{BET}}$ was obtained by the Brunauer-Emmett-Teller (BET) method and the pore size distribution was gained from Nonlocal Density Functional Theory (NLDFT).

\subsection{Adsorption experiments and kinetic studies}

MB solution with concentration of $500 \mathrm{mg} / \mathrm{L}$ was prepared for adsorption experiments in advance. The commercial AC (YP-80) was utilized as a control group. $\mathrm{AC}(100 \mathrm{mg})$ and $\mathrm{MB}$ solution $(100 \mathrm{~mL})$ were added into the beaker and magnetically stirred at room temperature $\left(\sim 25{ }^{\circ} \mathrm{C}\right)$. The sampling intervals were $2,4,6,8,10,15$, $20,25,30,45,60,90,120$ and $180 \mathrm{~min}$. After highly speed centrifugation, the supernatant was extracted for analyzing its absorbance on the UV-visible spectrometer (Hitachi U4100) equipped with an integrating sphere. All tests were conducted at a specific wavelength, namely, the maximum absorbance $(664 \mathrm{~nm})$ of $\mathrm{MB}$ at room temperature. The correlation between absorbance and the MB concentration is determined according to the Lambert-Beer's Law ${ }^{[18]}$. Afterwards, the amount of each carbon addition dwindled gradually until the adsorption limit appeared.

Adsorption capacity $\left(q_{\mathrm{e}}\right)$ at equilibrium was calculated by the Equation $(1)^{[19]}$ :

$$
q_{\mathrm{e}}=\frac{\left(C_{0}-C_{\mathrm{e}}\right) \mathrm{V}}{m}
$$

where $q_{\mathrm{e}}(\mathrm{mg} / \mathrm{g})$ is the adsorption capacity of $\mathrm{MB}$ at equilibrium, $C_{0}(\mathrm{mg} / \mathrm{L})$ is the primitive concentration of the MB solution $(500 \mathrm{mg} / \mathrm{L}), C_{\mathrm{e}}(\mathrm{mg} / \mathrm{L})$ is the equilibrium 
concentration of the $\mathrm{MB}$ solution, $V(\mathrm{~L})$ is the $\mathrm{MB}$ solution volume i.e. $0.1 \mathrm{~L}, \mathrm{~m}(\mathrm{~g})$ is the mass of added RHAC.

The pseudo-first-order models (Equation (2)) and the pseudo-second order models (Equation (3)) were utilized to fit the adsorption data for describing the adsorption equilibrium $^{[20]}$ :

$$
\begin{gathered}
q_{t}=q_{\mathrm{e}}\left(1-\mathrm{e}^{-k_{1} t}\right) \\
q_{t}=\frac{q_{\mathrm{e}}^{2} k_{2} t}{1+k_{2} q_{\mathrm{e}} t}
\end{gathered}
$$

where $q_{t}(\mathrm{mg} / \mathrm{g})$ is the adsorption capacity at time $t, q_{\mathrm{e}}$ $(\mathrm{mg} / \mathrm{g})$ is the adsorption capacity of MB at equilibrium, $k_{1}$ and $k_{2}$ are the rate constant of the pseudo-first-order $\left(\min ^{-1}\right)$ and the pseudo-second-order $\left(\min ^{-1}\right)$, respectively, $t$ $(\mathrm{min})$ is the adsorption time.

\section{Results and discussion}

The morphologies of raw RHs, RHBC and RHACs were characterized by SEM. Obviously, there are many humps on the outer glume of raw RHs and RHBC (Fig. 1(a,b)). The surface of humps in RHs is intact. After heat-treated at $400{ }^{\circ} \mathrm{C}$, lots of large opening pores appear on the surface of RHBC to conduce to activator- $\mathrm{KOH}$ enter the interior of RHBC for enhancing the process of activation $^{[1]}$. The commercial AC (YP-80) shows fine granular blocks, and the visible pores are hard to find out (Fig. 1(c)). After activation, the abundant pore structure forms on the sample surface, which can provide adsorption sites and mass transfer channels in favor of adsorption application (Fig. 1(d-g) $)^{[9]}$. The inner side of RHs is activated to form spongy structure, and the outer surface of RHs forms honeycomb structure due to natural composition and structure of RHs (Fig. 1(d, e) $)^{[16]}$. With the activation temperature increasing, the process of forming pores is strengthened resulting in that the pore structure of RHAC900 is more abundant than that of RHAC800 (Fig. 1(f, g)). The porous structure was further examined by HRTEM. The RHAC 900 mainly consists of amorphous carbon and plenty of vermicular micropores, in which a few graphitized carbon layers exist.

As shown in Fig. 2(a), the inapparent peaks appear at around $2 \theta=23^{\circ}$ and $44^{\circ}$ suggesting that RHACs and YP-80 are composed of amorphous carbon ${ }^{[21]}$. Broad peak around $2 \theta=22^{\circ}$ in RHBC indicates the overlapping peaks of carbon and silica, and the decrease of peak intensity suggests that $\mathrm{SiO}_{2}$ is almost completely removed (Fig. S1). Lignin and cellulose in precursors undergo a pyrolysis process at $400{ }^{\circ} \mathrm{C}$, in which the tar is formed from highly active polymer materials and releases, leaving inert carbon skeleton and amorphous
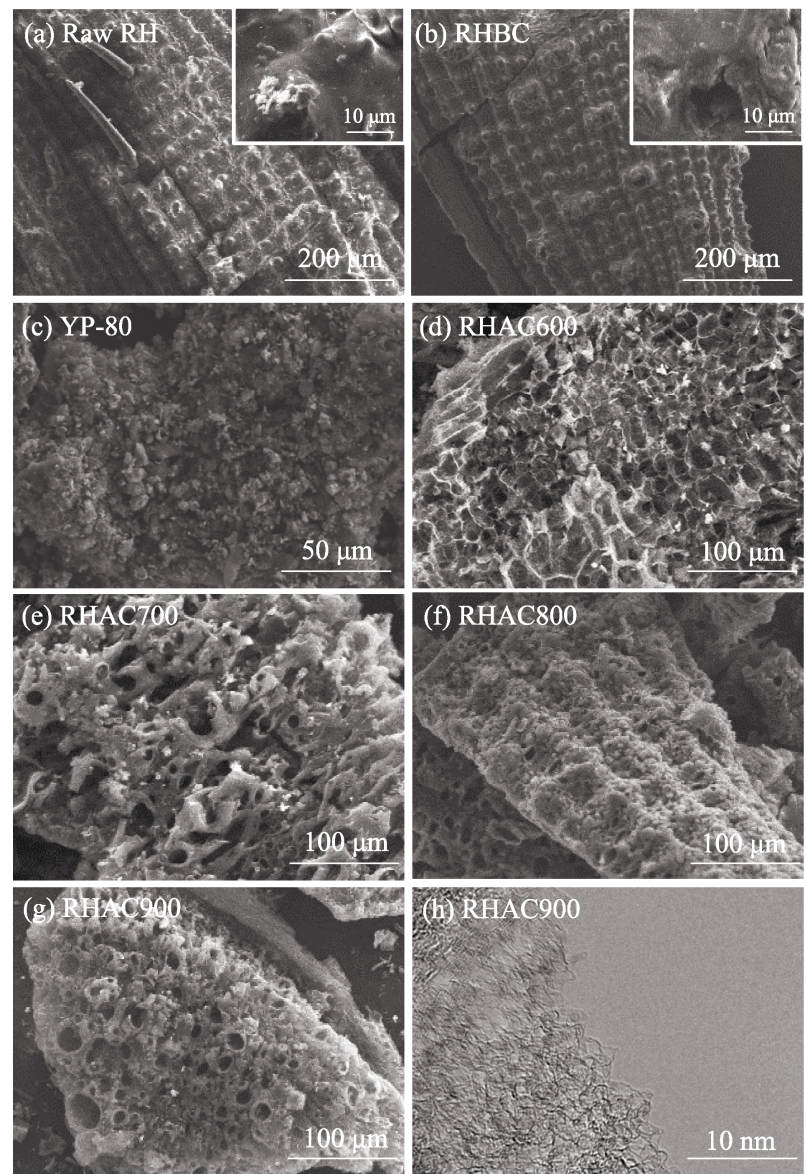

Fig. 1 SEM images of (a) raw RHs, (b) RHBC, (c) YP-80, (d) RHAC600, (e) RHAC700, (d) RHAC800; SEM (g), and TEM (h) images of RHAC 900

$\mathrm{SiO}_{2}$, which shows strong but wide peak at around $2 \theta=22^{\circ}$ (Fig. 2(a)). In the process of activation at high temperature, the amorphous nano- $\mathrm{SiO}_{2}$ was melted in the presence of $\mathrm{KOH}$ and eliminated at last, weakening the intensity of peaks at around $2 \theta=22^{\circ[15]}$.

Meanwhile, a part of carbon in RHBC reacts with $\mathrm{KOH}$ to produce $\mathrm{CO}$ and $\mathrm{CO}_{2}$ gases, resulting in abundant pores formation and the increasement of the degree of disorder in RHACs ${ }^{[22]}$.

Raman spectra of the RHACs and YP-80 contains D-band (1342-1352 $\mathrm{cm}^{-1}$ ), G-band (1590-1600 $\mathrm{cm}^{-1}$ ) (Fig. 2(b)). Normally, the graphitization degree of carbon increases gradually with the increase of the heattreatment temperature ${ }^{[23]}$. However, with the activation temperature increasing, the ratio of D-band to G-band increases slightly (Table 1), resulting from that the disorder degree due to consuming carbon during activation has larger influence on the crystallinity of products than temperature ${ }^{[24]}$.

The SSA $\mathrm{BET}_{\text {B }}$ of RHACs was characterized by BET test, as shown in Fig. 2(c). There exists two types of $\mathrm{N}_{2}$ adsorption-desorption isotherm curves, type- I for YP-80, RHAC600, RHAC700, RHAC800 and type-IV for 

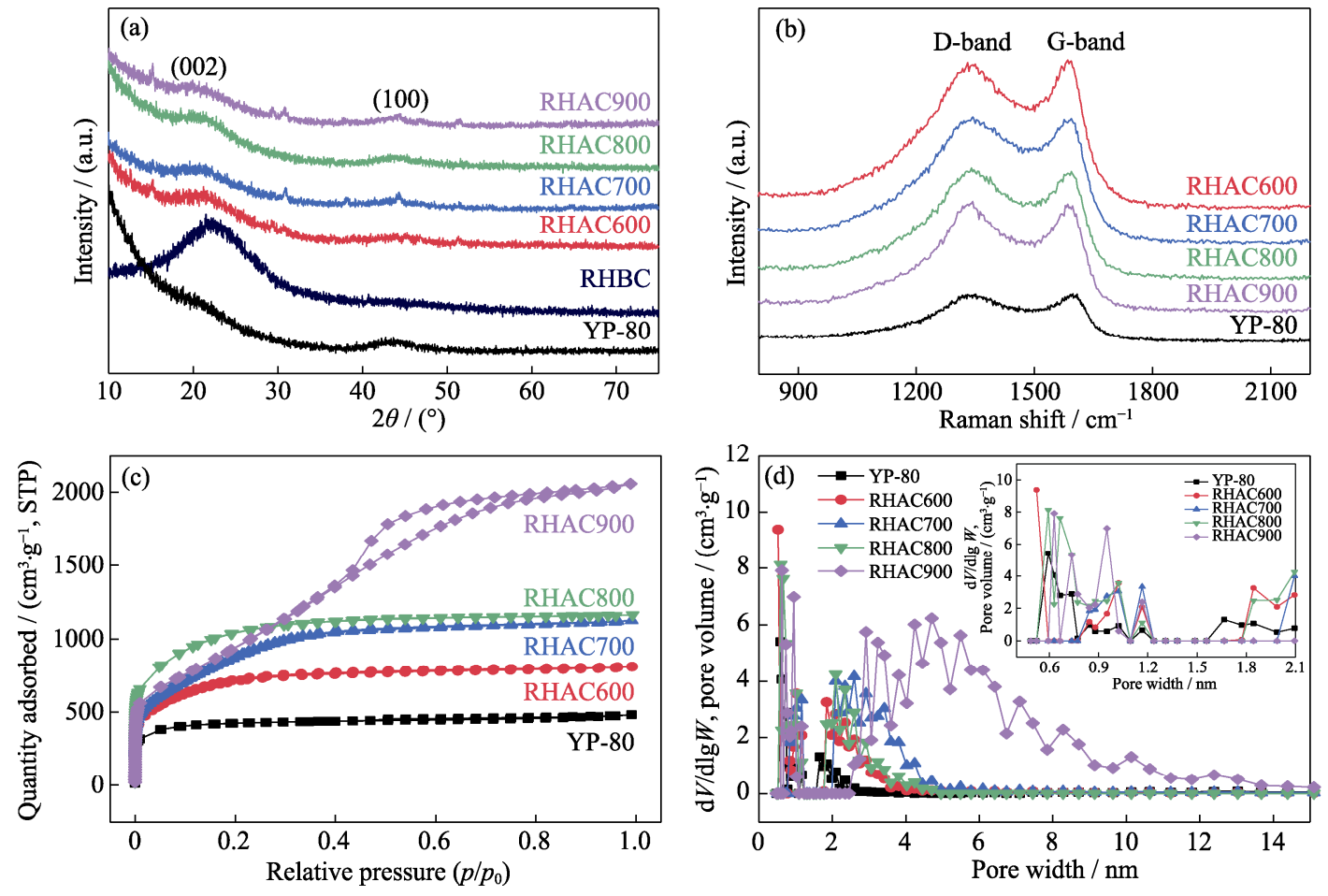

Fig. 2 (a) XRD patterns, (b) Raman spectra, (c) $\mathrm{N}_{2}$ adsorption-desorption isotherms and

(d) pore size distribution curves of RHBC, RHACs and YP-80

Table 1 The ratio of $I_{\mathrm{D}}$ to $I_{\mathrm{G}}$, $\mathrm{SSA}_{\mathrm{BET}}$, pore volumes ${ }_{\text {total }}$, micropore volumes and adsorption limits of RHACs and YP-80

\begin{tabular}{lccccc}
\hline \multicolumn{1}{c}{ Carbon } & YP-80 & RHAC600 & RHAC700 & RHAC800 & RHAC900 \\
\hline$I_{\mathrm{D}}: I_{\mathrm{G}}$ & 0.997 & 0.992 & 1.017 & 1.025 & 1.020 \\
$\mathrm{SSA}_{\mathrm{BET}} /\left(\mathrm{m}^{2} \cdot \mathrm{g}^{-1}\right)$ & 1310 & 2380 & 3173 & 3366 & 3600 \\
Pore volume $_{\text {total }} /\left(\mathrm{cm}^{3} \cdot \mathrm{g}^{-1}\right)$ & 0.816 & 1.352 & 1.733 & 1.829 & 3.164 \\
Micropore volume $/\left(\mathrm{cm}^{3} \cdot \mathrm{g}^{-1}\right)$ & 0.516 & 0.393 & 0.429 & 0.606 & 0.537 \\
Adsorption limit $/\left(\mathrm{mg}^{-1}\right)$ & 525 & 851 & 935 & 919 & 983 \\
\hline
\end{tabular}

RHAC900. The curves of type-I conform to Langmuir's monolayer adsorption model indicating that the pore structure is mainly composed of micropores, and the obvious hysteresis loop in the type-IV curve for RHAC900 shows that abundant mesopores exist in this material, well explaining why the total pore volume and the pore size distribution of RHAC900 are far greater than other porous materials (Table 1$)^{[25]}$. The $\mathrm{SSA}_{\mathrm{BET}}$ and the total pore volumes of RHACs are positively correlated with activation temperature, and reach the highest value of $3600 \mathrm{~m}^{2} / \mathrm{g}$ and $3.164 \mathrm{~cm}^{3} / \mathrm{g}$ for RHAC900 (Table 1). Supersaturated $\mathrm{KOH}$ solution can react with $\mathrm{SiO}_{2}$ in $\mathrm{RHBC}$ to form $\mathrm{K}_{2} \mathrm{SiO}_{3}$ during the process of impregnation and dry, contributing to pre-activation (Fig. S2(a)). The formation of $\mathrm{K}_{2} \mathrm{SiO}_{3}$ makes the original vacancy of self-template $\mathrm{SiO}_{2}$ exposed and drives the activator into a deeper position to promote the activation process. Accordingly, the sample

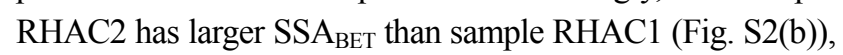
and the sample RHAC900 has larger $\mathrm{SSA}_{\mathrm{BET}}$ compared with ACs made from other biomass materials by traditional preparation methods (Table S1). Although RHACs mainly contain micropores, there are still a small number of mesopores in these materials (Table 1). The mesopore size in RHAC600 ranges from $2 \mathrm{~nm}$ to $4 \mathrm{~nm}$, tightly close to the range of micropore ${ }^{[12]}$. With the activation temperature increasing, more carbon in RHBC reacted with molten $\mathrm{KOH}$, and the pore-forming process strengthened intensely, causing the size of pores to widen $^{[15,24]}$. Therefore, the mesopore size in RHAC900 enlarges from $2.5 \mathrm{~nm}$ to $14 \mathrm{~nm}$. The $\mathrm{SSA}_{\mathrm{BET}}$ and mesopore size of RHACs are superior to YP-80 (Table 1). In the range of micropore size, the peak intensities of micropore distribution curves of RHACs are stronger than those of YP-80. Although the micropore volume of YP-80 is slightly higher than those of RHAC600 and RHAC700, the micropore volumes of RHAC800 and RHAC900 are higher than that of YP-80 and the total pore volume of RHACs are much larger (Table 1). The above characterization results reveal that the activation temperature has tremendous impact on the activation 
process and pore structure of RHACs. As the temperature increasing, the activation process becomes more violent, and more carbon is consumed, leading to the increasement of mesoporous content and size.

The temperature $\left(\sim 25^{\circ} \mathrm{C}\right)$, initial concentration of MB solution $(500 \mathrm{mg} / \mathrm{L})$ and contact time $(180 \mathrm{~min})$ were set up to estimate the MB adsorption performance of RHACs and YP-80. As the amount of adsorbent decreasing, the adsorption limit of RHACs and YP-80 appeared one by one, as shown in Fig. 3(a, d). The adsorption efficiency and capacity are associated with the $\mathrm{SSA}_{\mathrm{BET}}$, and the higher the specific surface area, the larger the adsorption capacities $^{[25]}$. As shown in Table 1, the maximum adsorption capacity is $983 \mathrm{mg} / \mathrm{g}$ for the RHAC900 which possesses the highest $\mathrm{SSA}_{\mathrm{BET}}$ of $3600 \mathrm{~m}^{2} / \mathrm{g}$. Nevertheless, the adsorption capacity of the RHAC800 $(919 \mathrm{mg} / \mathrm{g})$ is slightly lower than that of the RHAC700 (935 mg/g). In the case of ultra-high $\mathrm{SSA}_{\mathrm{BET}}\left(>3000 \mathrm{~m}^{2} / \mathrm{g}\right)$, the minute difference of $\mathrm{SSA}_{\mathrm{BET}}$ has no significant effect on adsorption capacity which is mainly affected by pore size and volume of materials ${ }^{[26]}$. As can be seen from Fig. 2(d), the mesopore size range of the RHAC700 is wider than that of RHAC800(as listed in Table 1), indicating higher adsorption capacity and faster mass transfer rate (the insets of Fig. 3(c,d)).

Meanwhile, due to the high $\mathrm{SSA}_{\mathrm{BET}}$ of $3600 \mathrm{~m}^{2} / \mathrm{g}$, the greatly wide mesoporous size distribution from $2.5 \mathrm{~nm}$ to $14 \mathrm{~nm}$ and ultra-large total pore volume of $3.164 \mathrm{~cm}^{3} / \mathrm{g}$, the RHAC900 has the highest adsorption capacity of $983 \mathrm{mg} / \mathrm{g}$. Although micropore volume of RHAC900 is
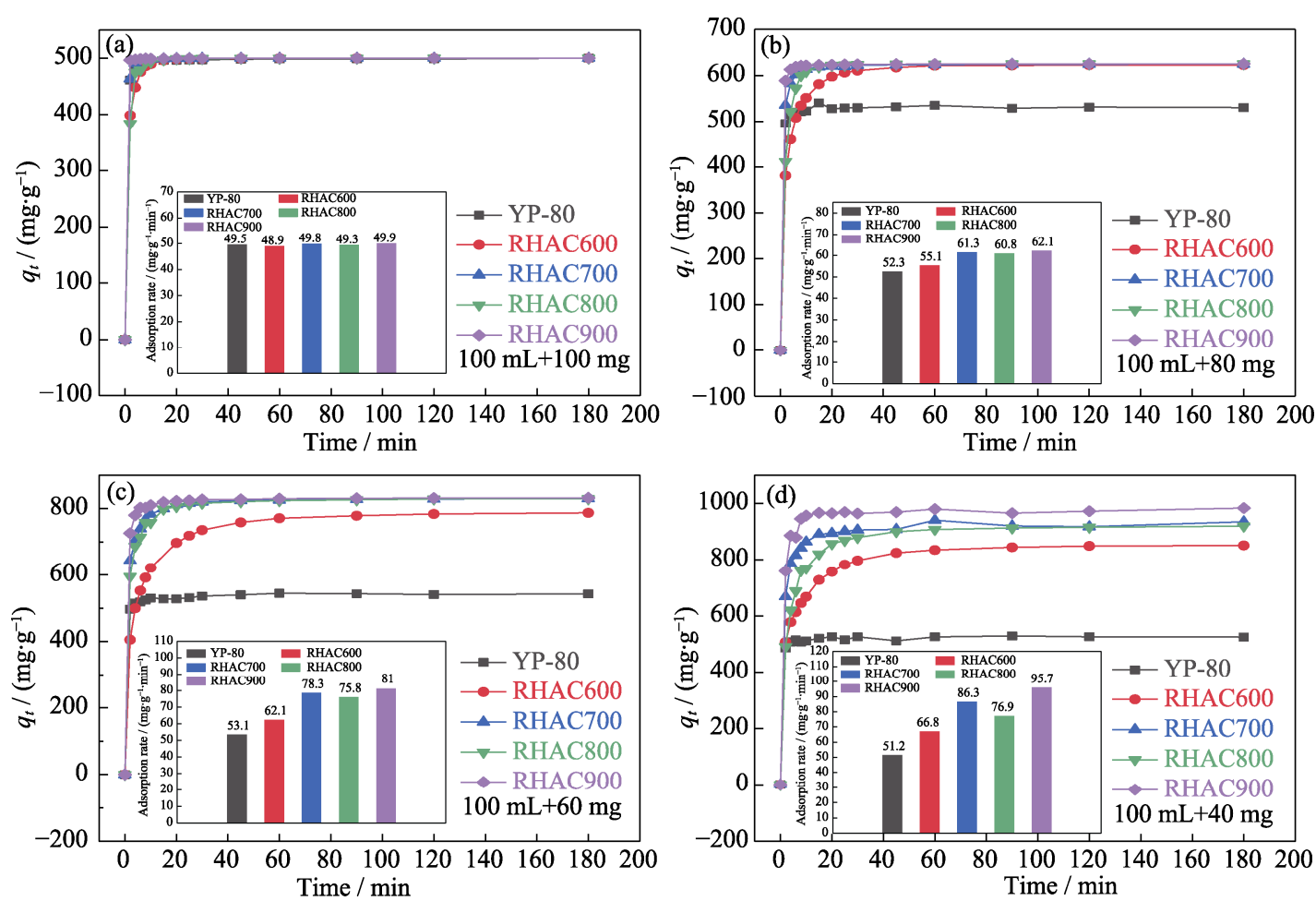

smaller than that of RHAC800 and close to others, the mesopore volume of RHAC900 is far larger than those of other RHACs (Table 1), resulting in fastest adsorption rate (Fig. 3(d) $)^{[27]}$. On the whole, all of RHACs exhibit more outstanding adsorption performance than the commercial AC (YP-80). As seen from Table S1, the $\mathrm{SSA}_{\mathrm{BET}}$ and pore volume have a crucial influence on the adsorption capacity for MB and the performance of RHAC in this study is much better than other carbon reported.

Kinetic studies were conducted to further understand the adsorption mechanism in the adsorption processes for $\mathrm{MB}$, and the pseudo-first-order model and the pseudosecond-order model were used to fit the adsorption data $^{[19]}$. For the fitting processes, the correlation coefficients $\left(R^{2}\right)$ are determined for two models and each adsorbent, and the higher value $R^{2}$ is deemed as the better fitting $^{[28]}$.

The linear fit of the pseudo-first-order model and the values of the correlation coefficients are shown in Fig. S3(a-f). The results indicate a relatively good linear fit for RHAC600 and RHAC800, with $R^{2}=0.9352$ and $R^{2}=0.938$, respectively. Table $\mathrm{S} 2$ shows the values of the kinetic adsorption constants obtained from the application of the pseudo-first-order model for each RHAC. Only when the difference between $q_{\mathrm{e}}$ (experimental) and $q_{1}$ (calculated) is the smallest possible, the kinetic models are significant ${ }^{[28]}$. However, all differences between those parameters exceed $45 \%$. Hence, the pseudo-first- order model can't describe the adsorption process of these carbon.

Fig. 3 Effects of contact time and mass of adsorbent on the adsorption capacity 

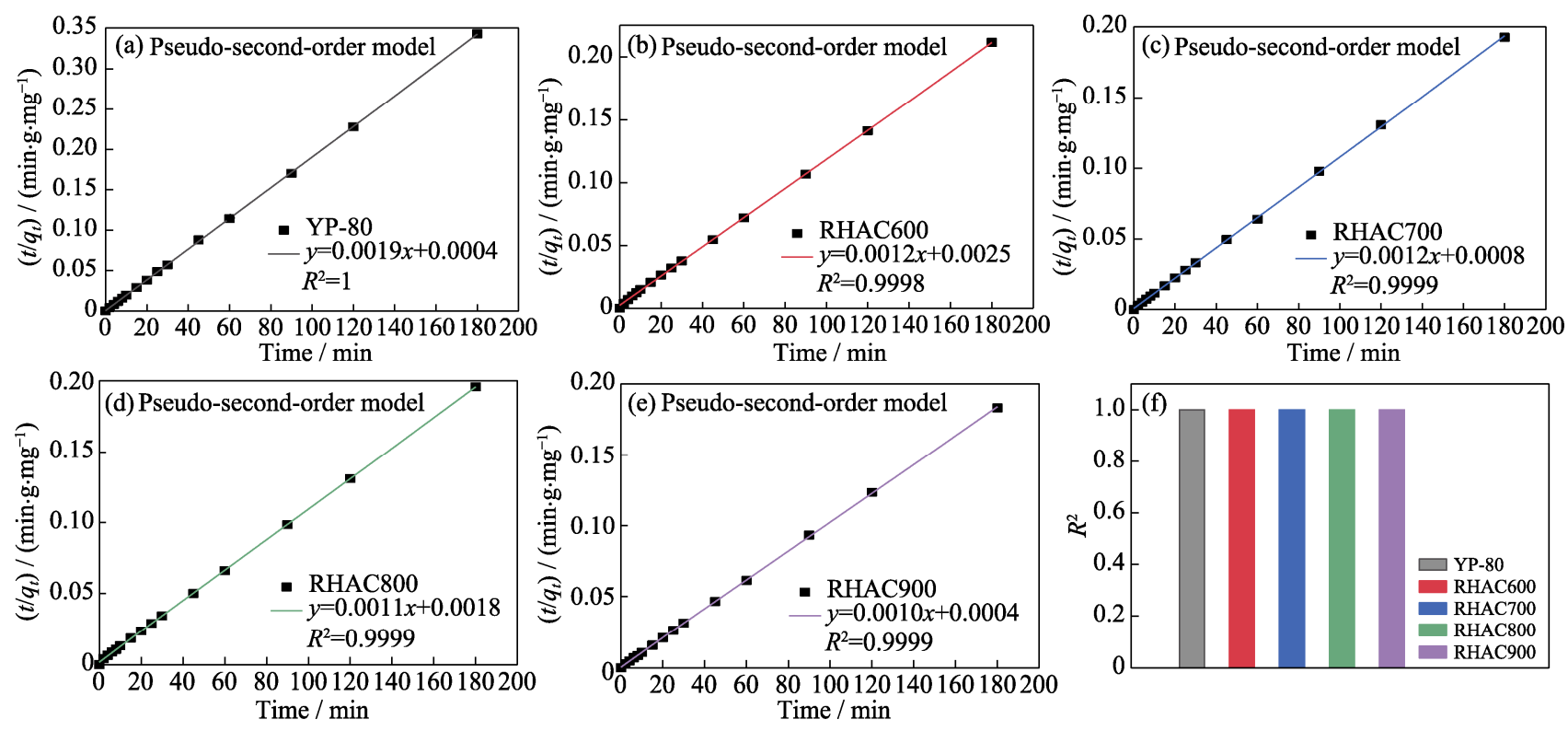

Fig. 4 Linear fits of the pseudo-second-order models for the adsorption of MB on (a) YP-80, (b) RHAC600,

(c) RHAC700, (d) RHAC800, (e) RHAC900, and (f) corresponding correlation coefficients

The linear fit of the pseudo-second-order model and the values of the correlation coefficients are shown in Fig. 4(a-f). The results indicate a perfect linear fit for RHACs and YP-80. All of the correlation coefficients $\left(R^{2}\right)$ are extremely close to 1 suggesting that the pseudosecond-order model can precisely describe the adsorption process of MB. Meanwhile, in Table 2, all of the difference between $q_{\mathrm{e}}$ (experimental) and $q_{2}$ (calculated) of each sample are also small enough to confirm that the adsorption process is consistent with the pseudo-secondorder model.

The results of kinetic fitting indicate that the possible chemisorption of MB on the surface of RHAC may be realized by forming chemical complexes with functional groups ${ }^{[29]}$. All products only contain $\mathrm{C}$ and $\mathrm{O}$ leading to pretty low ash content (Table S3 \& S4, Fig. S4) and oxygen-containing functional groups on the surface. The broad band at $3456 \mathrm{~cm}^{-1}$ is due to the $\mathrm{O}-\mathrm{H}$ stretching mode of hydroxyl groups (from carboxyl groups, phenols or alcohols) and adsorbed water. The band at $1597 \mathrm{~cm}^{-1}$ is attributed to $\mathrm{C}-\mathrm{O}$ stretching vibration from ketones, aldehydes, lactones or carboxyl groups. The peak at

Table 2 Kinetic parameters obtained of RHACs and YP-80 by the pseudo-second-order model for the adsorption of $\mathrm{MB}$

\begin{tabular}{lcccc}
\hline Sample & $\begin{array}{c}q_{\mathrm{e}}(\mathrm{exp}) / \\
\left(\mathrm{mg} \cdot \mathrm{g}^{-1}\right)\end{array}$ & $\begin{array}{c}q_{2}(\mathrm{cal}) / \\
\left(\mathrm{mg} \cdot \mathrm{g}^{-1}\right)\end{array}$ & $\begin{array}{c}\text { Percentual } \\
\text { difference } \\
\left(q_{\mathrm{e}}-q_{2}\right) / \%\end{array}$ & $\begin{array}{c}k_{2} /\left(\mathrm{g} \cdot \mathrm{mg}^{-1}\right. \\
\left.\mathrm{min}^{-1}\right)\end{array}$ \\
\hline YP-80 & 525 & 526.3 & -0.25 & 0.0090 \\
RHAC600 & 851 & 833.3 & 2.08 & 0.0006 \\
RHAC700 & 935 & 833.3 & 10.88 & 0.0018 \\
RHAC800 & 919 & 909.1 & 1.08 & 0.0007 \\
RHAC900 & 983 & 1000 & -1.73 & 0.0025 \\
\hline
\end{tabular}

$1357 \mathrm{~cm}^{-1}$ is assigned to $\mathrm{C}-\mathrm{O}$ stretching and $\mathrm{O}-\mathrm{H}$ bending modes of alcoholic, phenolic and carboxylic groups. After adsorption for MB, the intensity of band decreased and the frequency of several groups changed, which indicates that the chemisorption occurred between MB and RHAC (Fig. S5). Therefore, the results of kinetic fitting are consistent with the FT-IR characterization. This adsorption mechanism can promote the clear adsorption of the adsorbent surface without allowing its reuse ${ }^{[28]}$.

\section{Conclusion}

As considering that RHs possess intrinsic advantages of structure and compositions, AC with ultra-large specific surface area from RHs are successfully synthesized through pre-activation and activation by supersaturated $\mathrm{KOH}$ solution. All of these activated carbon materials have hierarchical pore structure, larger specific surface area and larger pore volume compared with the commercial carbon (YP-80) and carbon materials based on other agricultural bio-waste. The RHAC with largest $\mathrm{SSA}_{\mathrm{BET}}$ of $3600 \mathrm{~m}^{2} / \mathrm{g}$ is prepared at $900{ }^{\circ} \mathrm{C}$ and performs the adsorption capacity of $983 \mathrm{mg} / \mathrm{g}$, which is almost twice as high as that of YP-80. Due to hierarchical pore structure in favor of adsorbing and transporting MB, the adsorption capacity of RHACs is superior to that of YP-80. The fitting results of the adsorption of MB on the RHs conforms the pseudo-second-order model indicating a chemisorption process. This study provides a feasible method for the reuse of RHs waste and large-scale preparation of AC with large specific surface area for water treatment. 


\section{Supporting materials}

Supporting materials related to this article can be found at https://doi.org/10.15541/jim20200632.

\section{References:}

[1] MENYA E, OLUPOT P W, STORZ H, et al. Production and performance of activated carbon from rice husks for removal of natural organic matter from water: a review. Chemical Engineering Research and Design, 2018, 129: 271-296.

[2] YAGUB M T, SEN T K, AFROZE S, et al. Dye and its removal from aqueous solution by adsorption: a review. Advances in Colloid and Interface Science, 2014, 209: 172-84.

[3] ZHOU Y, LU J, ZHOU Y, et al. Recent advances for dyes removal using novel adsorbents: a review. Environmental Pollution, 2019, 252: 352-365.

[4] SILVA L A D, BORGES S M S, PAULINO P N, et al. Methylene blue oxidation over iron oxide supported on activated carbon derived from peanut hulls. Catalysis Today, 2017, 289: 237-248.

[5] GUO Z, XIAO Z, REN G, et al. Natural tea-leaf-derived, ternarydoped 3D porous carbon as a high-performance electrocatalyst for the oxygen reduction reaction. Nano Research, 2016, 9(5): 1244-1255.

[6] DUAN X, SRINIVASAKANNAN C, WANG X, et al. Synthesis of activated carbon fibers from cotton by microwave induced $\mathrm{H}_{3} \mathrm{PO}_{4}$ activation. Journal of the Taiwan Institute of Chemical Engineers, 2017, 70: 374-381.

[7] TAN I A W, AHMAD A L, HAMEED B H. Adsorption of basic dye on high-surface-area activated carbon prepared from coconut husk: equilibrium, kinetic and thermodynamic studies. Journal of Hazardous Materials, 2008, 154(1-3): 337-346.

[8] CHOMA J, OSUCHOWSKI L, MARSZEWSKI M, et al. Developing microporosity in $\operatorname{Kevlar} \AA$-derived carbon fibers by $\mathrm{CO}_{2}$ activation for $\mathrm{CO}_{2}$ adsorption. Journal of $\mathrm{CO}_{2}$ Utilization, 2016, 16: 17-22.

[9] LIU Q X, ZHOU Y R, WANG M, et al. Adsorption of methylene blue from aqueous solution onto viscose-based activated carbon fiber felts: Kinetics and equilibrium studies. Adsorption Science \& Technology, 2019, 37(3/4): 312-332.

[10] PATAWAT C, SILAKATE K, CHUAN-UDOM S, et al. Preparation of activated carbon from Dipterocarpus alatus fruit and its application for methylene blue adsorption. RSC Advances, 2020, 10(36): 21082-21091.

[11] ZHU G, XING X, WANG J, et al. Effect of acid and hydrothermal treatments on the dye adsorption properties of biomass- derived activated carbon. Journal of Materials Science, 2017, 52(13): 7664-7676.

[12] LI D, YAN J, LIU Z, et al. Adsorption kinetic studies for removal of methylene blue using activated carbon prepared from sugar beet pulp. International Journal of Environmental Science and Technology, 2016, 13(7): 1815-1822.

[13] MUDYAWABIKWA B, MUNGONDORI H H, TICHAGWA L, et al. Methylene blue removal using a low-cost activated carbon adsorbent from tobacco stems: kinetic and equilibrium studies. Water Science \& Technology, 2017, 75(10): 2390-2402.
[14] MI B, WANG J, XIANG H, et al. Nitrogen self-doped activated carbons derived from bamboo shoots as adsorbent for methylene blue adsorption. Molecules, 2019, 24(16): 3012.

[15] WANG Z, SMITH A T, WANG W, et al. Versatile nanostructures from rice husk biomass for energy applications. Angewandte Chemie International Edition, 2018, 57(42): 13722-13734.

[16] CHEN Z, XU Y, SHIVKUMAR S. Microstructure and tensile properties of various varieties of rice husk. Journal of the Science of Food and Agriculture, 2018, 98(3): 1061-1070.

[17] CHEN Z, WANG X, XUE B, et al. Rice husk-based hierarchical porous carbon for high performance supercapacitors: The structureperformance relationship. Carbon, 2020, 161: 432-444.

[18] ISLAM M A, AHMED M J, KHANDAY W A, et al. Mesoporous activated carbon prepared from $\mathrm{NaOH}$ activation of rattan (Lacosperma secundiflorum) hydrochar for methylene blue removal. Ecotoxicology Environmental Safety, 2017, 138: 279-285.

[19] ISLAM M A, SABAR S, BENHOURIA A, et al. Nanoporous activated carbon prepared from karanj (Pongamia pinnata) fruit hulls for methylene blue adsorption. Journal of the Taiwan Institute of Chemical Engineers, 2017, 74: 96-104.

[20] BASTA A H, LOTFY V F, HASANIN M S, et al. Efficient treatment of rice byproducts for preparing high-performance activated carbons. Journal of Cleaner Production, 2019, 207: 284-295.

[21] HE X, LING P, YU M, et al. Rice husk-derived porous carbons with high capacitance by $\mathrm{ZnCl}_{2}$ activation for supercapacitors. Electrochimica Acta, 2013, 105: 635-641.

[22] LOZANO-CASTELLÓ D, CALO J M, CAZORLA-AMORÓS D, et al. Carbon activation with $\mathrm{KOH}$ as explored by temperature programmed techniques, and the effects of hydrogen. Carbon, 2007, 45(13): 2529-2536.

[23] GAO Y, LI L, JIN Y, et al. Porous carbon made from rice husk as electrode material for electrochemical double layer capacitor. Applied Energy, 2015, 153: 41-47.

[24] LI C, HE D, HUANG Z H, et al. Hierarchical micro-/mesoporous carbon derived from rice husk by hydrothermal pre-treatment for high performance supercapacitor. Journal of The Electrochemical Society, 2018, 165(14): A3334-A3341.

[25] SPAGNOLI A A, GIANNAKOUDAKIS D A, BASHKOVA S. Adsorption of methylene blue on cashew nut shell based carbons activated with zinc chloride: the role of surface and structural parameters. Journal of Molecular Liquids, 2017, 229: 465-471.

[26] VADIVELAN V, KUMAR K V. Equilibrium, kinetics, mechanism, and process design for the sorption of methylene blue onto rice husk. Journal of Colloid and Interface Science, 2005, 286(1): 90-100.

[27] ÜNER O. Hydrogen storage capacity and methylene blue adsorption performance of activated carbon produced from Arundo donax. Materials Chemistry and Physics, 2019, 237: 121852.

[28] ORLANDI G, CAVASOTTO J, MACHADO F R, et al. An adsorbent with a high adsorption capacity obtained from the cellulose sludge of industrial residues. Chemosphere, 2017, 169: 171-180.

[29] MAHMOUDI K, HOSNI K, HAMDI N, et al. Kinetics and equilibrium studies on removal of methylene blue and methyl orange by adsorption onto activated carbon prepared from date pits-A comparative study. Korean Journal of Chemical Engineering, 2014, 32(2): 274-283. 


\title{
用稻壳制备亚甲基蓝高吸附容量的超高比表面积活性炭
}

\author{
周 帆 ${ }^{1,2}$, 毕 辉 ${ }^{1}$, 黄富强 ${ }^{1,2,3}$
}

(1. 中国科学院 上海硅酸盐研究所, 高性能陶瓷和超微结构国家重点实验室, 上海 $200050 ; 2$. 上海科技大学 物 理科学与技术学院, 上海 200031; 3. 北京大学 化学与分子工程学院, 稀土材料化学及应用国家重点实验室, 北京 100871)

摘 要: 活性炭因具有高比表面积和丰富的孔结构而被广泛应用于吸附水处理中的污染物。稻壳具有独特的组成和 微观结构, 是制备活性炭的优质碳源。以稻壳为原料, 利用过饱和 $\mathrm{KOH}$ 溶液的预活化和活化双重作用, 在不同温 度下制备出超高比表面积活性炭。随着活化温度的升高, 活性炭的比表面积和总孔容逐渐增大。900 ${ }^{\circ} \mathrm{C}$ 下制得的活 性炭具有超高比表面积, 达到 $3600 \mathrm{~m}^{2} / \mathrm{g}$, 总孔容为 $3.164 \mathrm{~cm}^{3} / \mathrm{g}$, 明显优于商用活性炭(YP-80, 比表面积为 $1310 \mathrm{~m}^{2} / \mathrm{g}$, 总孔容为 $0.816 \mathrm{~cm}^{3} / \mathrm{g}$ )。具有最高比表面积的稻壳活性炭对亚甲基蓝的最大吸附量达到 $983 \mathrm{mg} / \mathrm{g}$, 几乎是 YP-80 $(525 \mathrm{mg} / \mathrm{g})$ 的两倍。通过吸附动力学拟合, 吸附亚甲基蓝的过程与拟二级动力学模型一致, 表明该过程为化学吸附。 关＼cjkstart键 词: 稻壳; 超高比表面积; 活性炭; 吸附; 亚甲基蓝

中图分类号: TQ424 文献标志码: A 
Supporting Materials:

\title{
Ultra-large Specific Surface Area Activated Carbon Synthesized from Rice Husk with High Adsorption Capacity for Methylene Blue
}

\author{
ZHOU Fan ${ }^{1,2}$, BI Hui ${ }^{1}$, HUANG Fuqiang ${ }^{1,2,3}$
}

(1. State Key Laboratory of High Performance Ceramics and Superfine Microstructure, Shanghai Institute of Ceramics, Chinese Academy of Sciences, Shanghai 200050, China; 2. School of Physical Science and Technology, ShanghaiTech University, Shanghai 200031, China; 3. State Key Laboratory of Rare Earth Materials Chemistry and Applications, College of Chemistry and Molecular Engineering, Peking University, Beijing 100871, China)

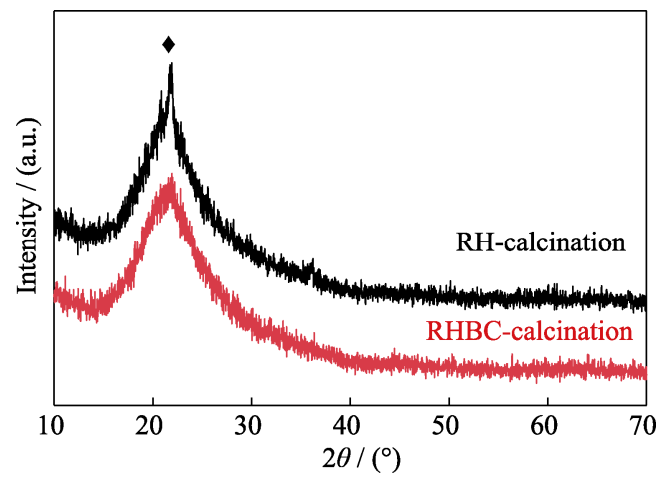

Fig. S1 XRD patterns of the product calcined from RHs and RHBC
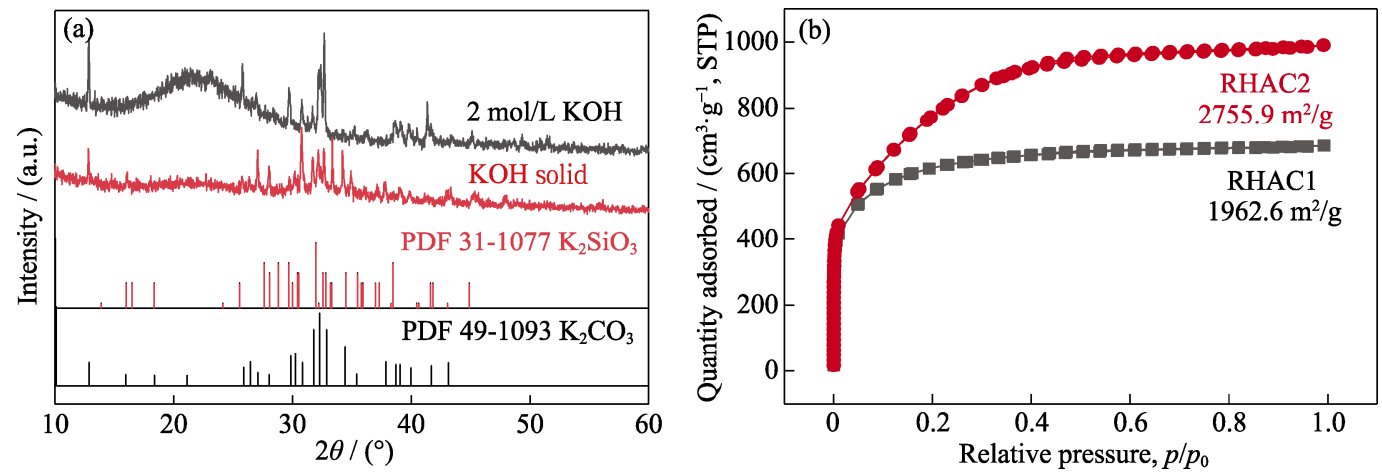

Fig. S2 (a) XRD patterns of dried RHBC mixture impregnated with two different concentrations of KOH solution;

(b) Nitrogen adsorption desorption curves of two RHAC with different concentrations of $\mathrm{KOH}$ solution

Table S1 Comparison of activator, SSA $\mathrm{BET}_{\mathrm{B}}$, total pore volume and $q_{\mathrm{m}}$ (the maximum adsorption of $\mathrm{MB}$ ) between RHACs and other AC prepared from biomass

\begin{tabular}{|c|c|c|c|c|}
\hline Biomass & Activator & Pore volume $/\left(\mathrm{cm}^{3} \cdot \mathrm{g}^{-1}\right)$ & $\mathrm{SSA}_{\mathrm{BET}} /\left(\mathrm{m}^{2} \cdot \mathrm{g}^{-1}\right)$ & $q_{\mathrm{m}} /\left(\mathrm{mg} \cdot \mathrm{g}^{-1}\right)$ \\
\hline Tobacco stalks $^{[1]}$ & $\mathrm{ZnCl}_{2}+$ Microwave & 0.45 & 684.68 & 123.45 \\
\hline Dipterocarpus alatus $^{[2]}$ & $\mathrm{ZnCl}_{2} / 500{ }^{\circ} \mathrm{C}$ & 0.473 & 843 & 269.3 \\
\hline Sugar beet pulp ${ }^{[3]}$ & $\mathrm{H}_{3} \mathrm{PO}_{4} / 450{ }^{\circ} \mathrm{C}$ & 0.445 & 1029.3 & 250.0 \\
\hline Palm kernel shell ${ }^{[4]}$ & $\mathrm{ZnCl}_{2} / 550{ }^{\circ} \mathrm{C}$ & 0.571 & 1058 & 225.3 \\
\hline Rice by-products ${ }^{[5]}$ & $\mathrm{H}_{3} \mathrm{PO}_{4} / 450{ }^{\circ} \mathrm{C}$ & $0.612 / 0.607$ & $814 / 1000$ & $246.9 / 213.7$ \\
\hline Viscose fibers $^{[6]}$ & Steam $/ 900{ }^{\circ} \mathrm{C}$ & $0.54 / 0.76$ & $1284 / 1614$ & $256.1 / 325.8$ \\
\hline Cotton $^{[7]}$ & $\mathrm{H}_{3} \mathrm{PO}_{4}+$ Microwave & 0.98 & 1370 & 476.2 \\
\hline Cashew nut shell ${ }^{[8]}$ & $\mathrm{ZnCl}_{2} / 400{ }^{\circ} \mathrm{C}$ & 0.973 & 1478 & 476 \\
\hline Arundo donax ${ }^{[9]}$ & $\mathrm{ZnCl}_{2} / 400{ }^{\circ} \mathrm{C}$ & 1.113 & 1784 & 416.7 \\
\hline Sawdust $^{[10]}$ & $\mathrm{KOH} / 1000{ }^{\circ} \mathrm{C}$ & 1.27 & 2254 & 303.03 \\
\hline Bamboo shoots $^{[11]}$ & $\mathrm{KHCO}_{3} / 700{ }^{\circ} \mathrm{C} / 800{ }^{\circ} \mathrm{C}$ & $0.73 / 1.25$ & $1476 / 2271$ & 458 \\
\hline Bagasse/Cluster stalks ${ }^{[12]}$ & $\mathrm{KOH} / 1300{ }^{\circ} \mathrm{C}$ & $0.82 / 1.4$ & $1861 / 2662$ & $714.3 / 925.9$ \\
\hline This work & $\mathrm{KOH} / 800{ }^{\circ} \mathrm{C} / 900{ }^{\circ} \mathrm{C}$ & $1.829 / 3.164$ & $3366 / 3600$ & $919 / 983$ \\
\hline
\end{tabular}



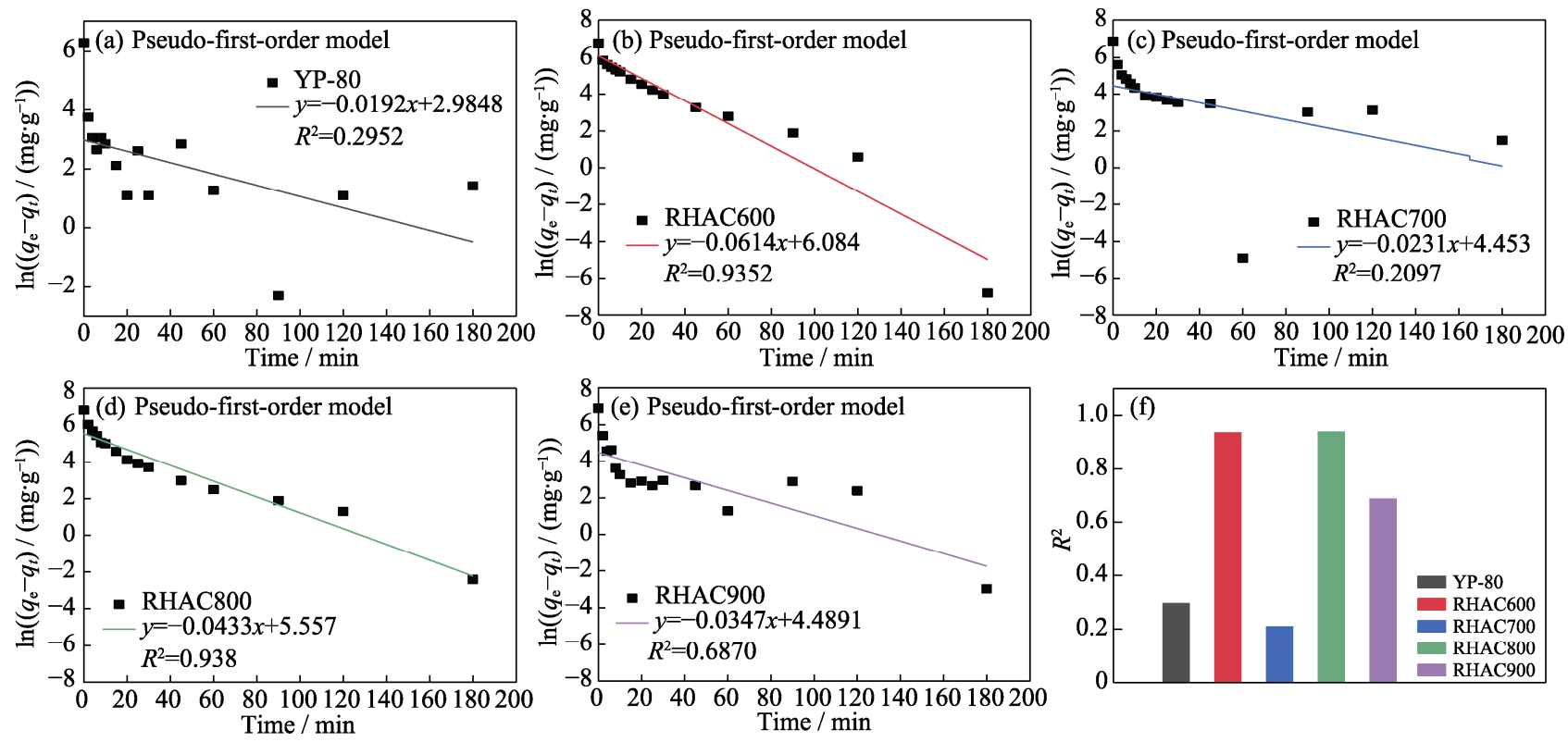

Fig. S3 Linear fits of the pseudo-first-order models for five carbons: (a) YP-80, (b) RHAC600,

(c) RHAC700, (d) RHAC800, (e) RHAC900 and (f) correlation coefficients

Table S2 Kinetic parameters obtained by the pseudo-first-order model for RHACs and YP-80 for the adsorption of MB

\begin{tabular}{ccccc}
\hline Sample & $q_{\mathrm{e}}(\mathrm{exp}) /\left(\mathrm{mg} \cdot \mathrm{g}^{-1}\right)$ & $q_{1}(\mathrm{cal}) /\left(\mathrm{mg} \cdot \mathrm{g}^{-1}\right)$ & Percentual difference, $\left(q_{\mathrm{e}}-q_{1}\right) / \%$ & $k_{1} / \mathrm{min}^{-1}$ \\
\hline YP-80 & 525 & 19.8 & 96.23 & 0.0192 \\
RHAC600 & 851 & 438.8 & 48.44 & 0.0614 \\
RHAC700 & 935 & 85.9 & 90.81 & 0.0231 \\
RHAC800 & 919 & 259 & 71.82 & 0.0433 \\
RHAC900 & 983 & 89 & 90.95 & 0.0347 \\
\hline
\end{tabular}

Table S3 Element analysis of RHBC, RHAC600, RHAC700, RHAC800 and RHAC900 by EDS/wt\%

\begin{tabular}{cccccc}
\hline & RHBC & RHAC600 & RHAC700 & RHAC800 & RHAC900 \\
\hline C & 19.48 & 95.18 & 97.21 & 94.16 & 95.63 \\
$\mathrm{O}$ & 35.59 & 4.82 & 2.79 & 3.15 & 2.28 \\
$\mathrm{Si}$ & 40.73 & 0 & 0 & 0 & 0 \\
$\mathrm{Ca}$ & 0.1 & 0 & 0 & 0 & 0 \\
\hline
\end{tabular}

Table S4 Mass and ash content of RH, RHBC, RHAC600, RHAC700, RHAC800 and RHAC900 before and after calcination

\begin{tabular}{lcccccc}
\hline & RH & RHBC & RHAC600 & RHAC700 & RHAC800 & RHAC900 \\
\hline Before/mg & 2502.0 & 1002.4 & 148.1 & 76.3 & 88.7 & 53.9 \\
After/mg & 375.0 & 330.0 & 0 & 0 & 0 & 0 \\
Ash content/\% & 14.99 & 32.92 & - & - & - & - \\
\hline
\end{tabular}

(a)

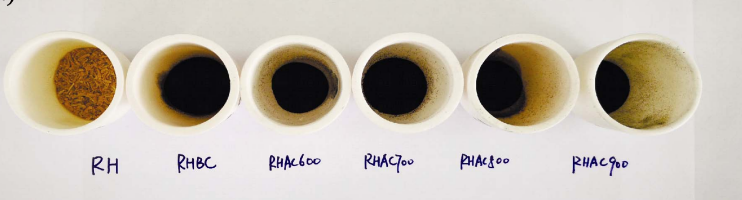

(b)

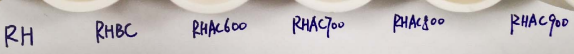

Fig. S4 Photos of RH, RHBC, RHAC600, RHAC700, RHAC800 and RHAC900 before and after calcination 


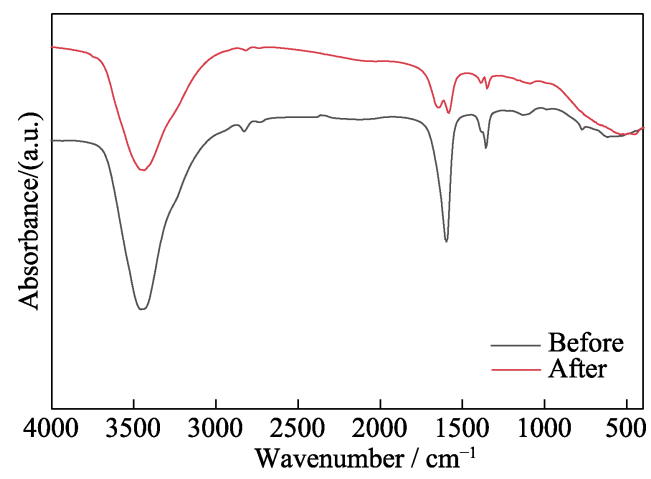

Fig. S5 FT-IR spectra of RHAC before and after MB adsorption

\section{References:}

[1] MUDYAWABIKWA B, MUNGONDORI H H, TICHAGWA L, et al. Methylene blue removal using a low-cost activated carbon adsorbent from tobacco stems: kinetic and equilibrium studies. Water Science \& Technology, 2017, 75(10): 2390-2402.

[2] PATAWAT C, SILAKATE K, CHUAN-UDOM S, et al. Preparation of activated carbon from Dipterocarpus alatus fruit and its application for methylene blue adsorption. RSC Advances, 2020, 10(36): 21082-21091.

[3] LI D, YAN J, LIU Z, et al. Adsorption kinetic studies for removal of methylene blue using activated carbon prepared from sugar beet pulp. International Journal of Environmental Science and Technology, 2016, 13(7): 1815-1822.

[4] GARCIA J R, SEDRAN U, ZAINI M A A, et al. Preparation, characterization, and dye removal study of activated carbon prepared from palm kernel shell. Environmental Science and Pollution Research, 2018, 25(6): 5076-5085.

[5] BASTA A H, LOTFY V F, HASANIN M S, et al. Efficient treatment of rice byproducts for preparing high-performance activated carbons. Journal of Cleaner Production, 2019, 207: 284-295.

[6] LIU Q X, ZHOU Y R, WANG M, et al. Adsorption of methylene blue from aqueous solution onto viscose-based activated carbon fiber felts: kinetics and equilibrium studies. Adsorption Science \& Technology, 2019, 37(3/4): 312-332.

[7] DUAN X, SRINIVASAKANNAN C, WANG X, et al. Synthesis of activated carbon fibers from cotton by microwave induced $\mathrm{H}_{3} \mathrm{PO}_{4}$ activation. Journal of the Taiwan Institute of Chemical Engineers, 2017, 70: 374-381.

[8] SPAGNOLI A A, GIANNAKOUDAKIS D A, BASHKOVA S. Adsorption of methylene blue on cashew nut shell based carbons activated with zinc chloride: the role of surface and structural parameters. Journal of Molecular Liquids, 2017, 229: 465-471.

[9] ÜNER O. Hydrogen storage capacity and methylene blue adsorption performance of activated carbon produced from Arundo donax. Materials Chemistry and Physics, 2019, 237: 121858.

[10] ZHU G, XING X, WANG J, et al. Effect of acid and hydrothermal treatments on the dye adsorption properties of biomass-derived activated carbon. Journal of Materials Science, 2017, 52(13): 7664-7676.

[11] MI B, WANG J, XIANG H, et al. Nitrogen self-doped activated carbons derived from bamboo shoots as adsorbent for methylene blue adsorption. Molecules, 2019, 24(16): 3012.

[12] ALCARAZ L, LÓPEZ FERNÁNDEZ A, GARCÍA-DÍAZ I, et al. Preparation and characterization of activated carbons from winemaking wastes and their adsorption of methylene blue. Adsorption Science \& Technology, 2018, 36(5/6): 1331-1351. 